\title{
DOES THE M-CHAT-R GIVE IMPORTANT INFORMATION FOR THE DIAGNOSIS OF THE AUTISM SPECTRUM DISORDER?
}

\section{Nada Pop-Jordanova ${ }^{1}$ and Tatjana Zorcec $^{2}$}

\author{
${ }^{1}$ Macedonian Academy of Sciences and Arts, Skopje, RN Macedonia \\ ${ }^{2}$ University Children's Hospital, Skopje, RN Macedonia
}

Corresponding author: Nada Pop-Jordanova, Bul Krste Misirkov br.2, P.O.Box 428, 1000 Skopje, RN Macedonia, e-mail: popjordanova.nadica@gmail.com

\begin{abstract}
Having in mind the rising rates of the incidence for autism worldwide, the early diagnosis of this neurodevelopmental disorder is of the high priority. For that purpose, several checklists have been constructed and used. Nevertheless, there are no universal and uniform criteria for assessing and diagnosing autism, and even if there existed, not every country has the resources to manage such an assessment for diagnosis. A recently validated, revised version of the M-CHAT, the M-CHAT-Revised with Follow up (M-CHAT$\mathrm{R} / \mathrm{F}$ ) has demonstrated strong psychometric properties.

The aim of this article is to discuss our results obtained with M-CHAT-R applied in a sample of 131 children aged 31,9 $\pm 9,4$ months, recruited for diagnosis and treatment at the University Children's Hospital in Skopje. Our results confirmed that for screening the use of M-CHAT-R/F is currently the very exact instrument which allows the early suspicion, but also possible follow up the symptoms of this disorder. Additionally, we showed the significant negative correlation between age and scores obtained on the checklist.
\end{abstract}

Keywords: autism, checklist, screening, neurodevelopmental disorder

\section{INTRODUCTION}

Autism Spectrum Disorder (ASD) is a combination of complex neurodevelopment disabilities, which is clinically characterized by impairments in language communication, varied cognitive deficits, and diminished social interaction. Moreover, it is characterized by repetitive, stereotyped, and restricted patterns of behaviours, interests, and activities. The diagnosis of ASD must follow the criteria described in the latest version of Diagnostic and Statistical Manual of Mental Disorders, 5th Edition (DSM-5) [1].
Currently, it seems that ASD becomes the most frequent children neurodevelopmental disorder which practically arises in epidemic form. According to the estimates from the Centres for Disease Control and Prevention (CDC), and Autism and Developmental Disabilities Monitoring (ADDM) Network, the prevalence rate for ASD is 18.5 per 1,000 , i.e., 1 in 54 children aged eight years. Within the last decades, the diagnostic rate of autism has increased dramatically, and it has been reported that cases of ASD have a rate of $0.6-0.8 \%$ in preschool children, $1.0 \%$ in school 
children and young adults, and around $1.0 \%$ in adults $[2,3]$.

It is well established that ASD is 4.3 times more prevalent among boys than among girls. For gender issues, most of the studies in children and adolescents have used a single item on the Child Behaviour Checklist (CBCL), a caregiver-report measure for behavioural problems, to quantify gender variance [4].

The diagnosis of ASD may occur across different age groups, though investigations and some researchers from different countries also indicate that autism already exists at the time of birth. Still, it is very challenging to obtain an early diagnosis. The American Academy of Paediatrics (AAP) suggested developmental screening of all children by the age of two years.

Nevertheless, there are no universal and uniform criteria for assessing and diagnosing autism, and even if they existed, not every country has the resources to manage such an assessment for diagnosis. This can lead to consideration and an explanation of the different figures of ASD prevalence among various countries around the world.

In clinical psychology and psychiatry, it is very important to find a valid, reliable and confident psychological instrument for testing patients with some mental problem. In this context, to construct a valid test for autism in a preclinical period is of great interest, having experience that the early treatment could provide the biggest success.

A number of validated measures are available to screen for ASD risk in children 18 months of age and older, including the Modified Checklist for Autism in Toddlers (M-CHAT) [5, 6, 7, $8,9]$.

A recently validated, revised version of the M-CHAT, the M-CHAT-Revised with Follow up (M-CHAT-R/F) [10-17] has demonstrated strong psychometric properties, with estimates of sensitivity and specificity of 0.854 and 0.993 in a low-risk, population-based sample.

\section{AIM OF THE STUDY}

The aim of this report is to analyse the obtained data for Modified Checklist for Autism in Toddlers, Revised (M-CHAT-R) in a sample of children evaluated and treated in the University Children Hospital in Skopje and to compare them with the clinical presentation.

\section{SAMPLE AND METHODOLOGY}

In this report we evaluate the main findings for a group of 131 children who were assessed, diagnosed and treated at the University Children's Hospital in Skopje. All of them have been directed from the paediatricians in primary care settings, mainly recruited from the capital town Skopje (more than 80\%). The sample was evaluated during the period of three years (2017end of 2019).

The mean age of the children was 31.9 \pm 9.4 months.

The assessment comprises detailed medical history, fulfil of the M-CHAT-R and clinical observation. The M-CHAT-R/F is valid for children 16-30 months old. It can be administered and scored as a part of a well-child care visit, and also can be used by specialists or other professionals to assess the risk for ASD. The primary goal of the M-CHAT-R is to maximize sensitivity, meaning to detect as many cases of ASD as possible. Therefore, not all children who score at risk will be diagnosed with ASD. To address this, the authors developed the Follow-Up questions (M-CHAT-R/F). Users should be aware that even with the Follow-Up, a significant number of the children who screen positive on the M-CHAT-R will not be diagnosed with ASD; however, these children are at high risk for other developmental disorders or delays, and therefore, evaluation is warranted for any child who screens positive. The M-CHAT-R can be scored in less than two minutes. It consists of 20 questions which must be answered with yes/no.

The questionnaire consists of parent report items which assess abnormal behaviours commonly associated with autism (i.e., reduced social interest, social play, pretend play, proto declarative pointing, and joint attention), as well as developmental behaviours that are more likely to be intact in children with autism (i.e., rough and tumble play, motor development, proto imperative pointing, and functional play). It was suggested in the Manuel that obtained score 0-2 represents a very low risk for ASD, the score 3-7 
represents a middle risk, and the score of 8-20 represents a very high risk for ASD.

\section{RESULTS AND DISCUSSION}

As it was mention before, the analysed data are for a group of 131 children, selected by chance, directed at the University Children's Hospital for evaluation and diagnosis of ASD. The mean age of the children was $31.9 \pm 9.4$ months, which is relatively early. In majority, mothers were the persons who bring the children, fathers were the caregiver in only three children. In this context, practically only mothers were the persons who fulfilled the questionnaire.

The gender ratio in the evaluated samples is presented on Fig. 1 and very clearly shows the predominance of boys' vs girls.

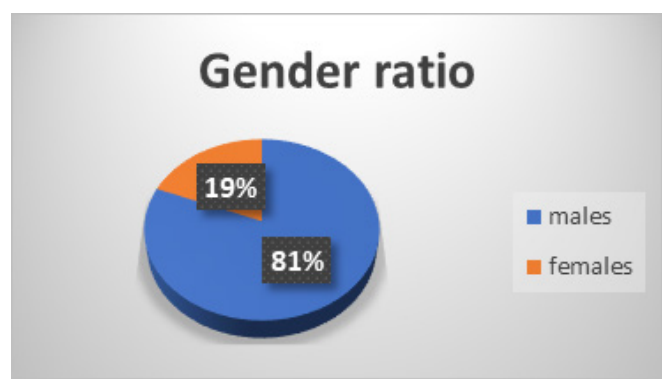

Fig. 1. Gender ratio in the evaluated sample of 131 children

As mentioned before, the obtained score $0-2$ is a very low risk for ASD, the score 3-7 represents a middle risk, and the score of 8-20 represents a very high risk for ASD. It is very clear that in our sample the obtained score for M-CHAT-R is very high, the mean values are $16.42 \pm 2.21$. The maximum score was 19 , and the minimum was 10 (all numbers over this score represents very high risk). The score obtained for every child is presented on Fig.2.

It must be accentuated, that all tested children have been directed to the Hospital because the paediatricians suspected the disorder, which means some kind of preselection. If the questionnaire was applied in primary care settings maybe the scores would be different.

However, we must say that the questionnaire gives us very available data for future diagnosis.

The calculated correlation between the age and scores obtained for M-CHAT-R is significant and negative (see chart below). It means that earlier scoring is much higher.

\begin{tabular}{|l|l|}
\hline \multirow{2}{*}{ Variable } & \multicolumn{2}{l|}{$\begin{array}{l}\text { Correlations (autism.sta) } \\
\text { Marked correlations are significant at } \mathrm{p}<.05000 \\
\mathrm{~N}=131 \text { (Casewise deletion of missing data) }\end{array}$} \\
\cline { 2 - 2 } & Score \\
\hline Age & -0.17 \\
\hline
\end{tabular}

The scatterplot for this correlation is presented in Fig.3.

\section{Scores for M-CHAT-R}

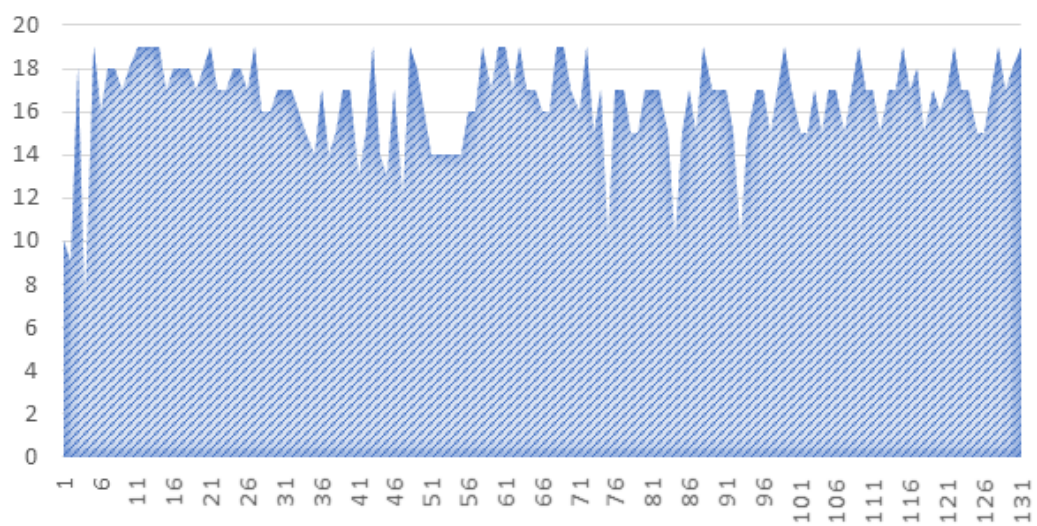

Fig. 2. Obtained scores for $M-C H A T-R$ 


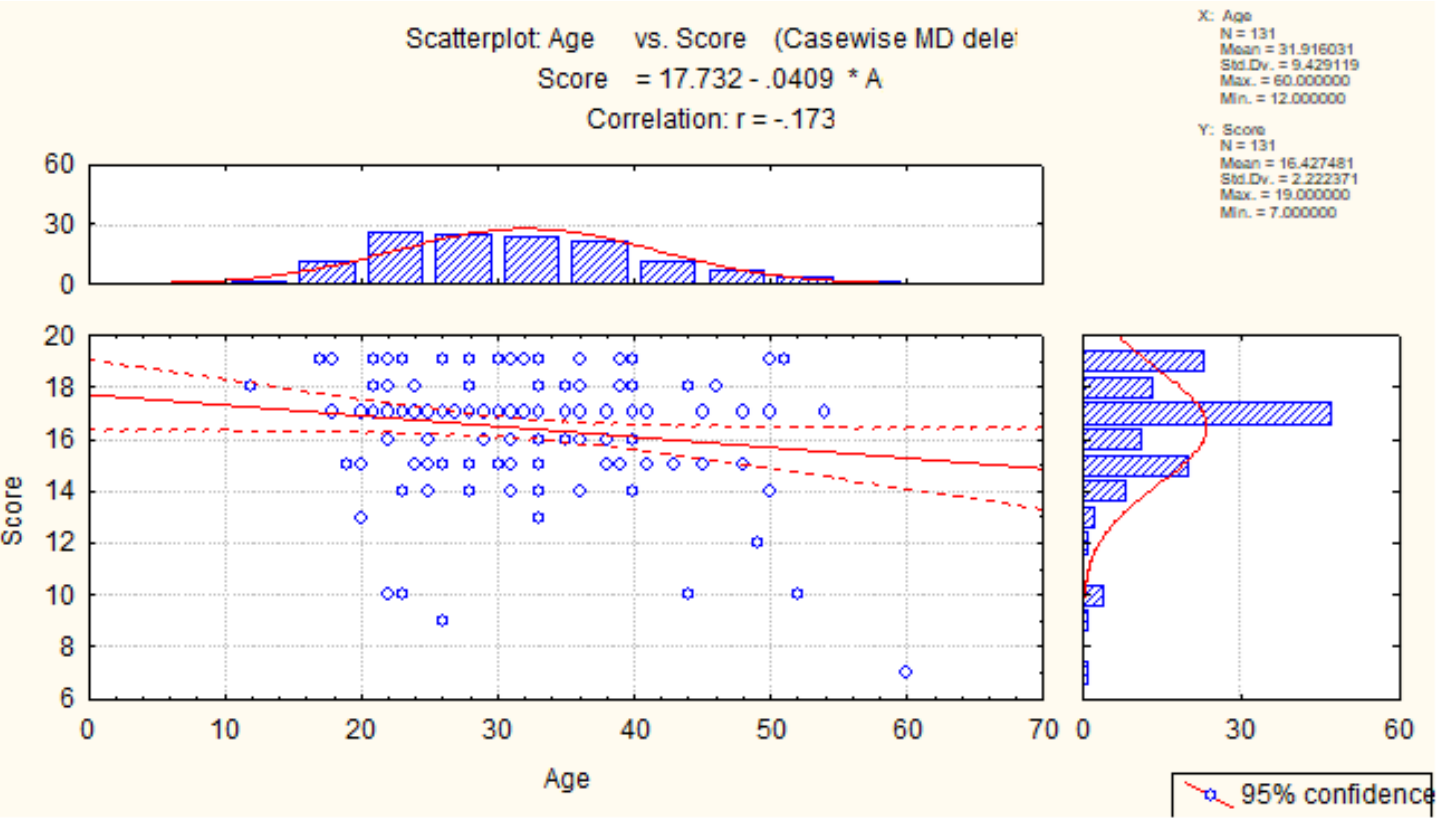

Fig. 3. Scatterplot for the correlation between age and scores Fig. 4.

For better visual representation, the same correlation is presented in bivariate histogram on Bivariate Histogram: Age and Score

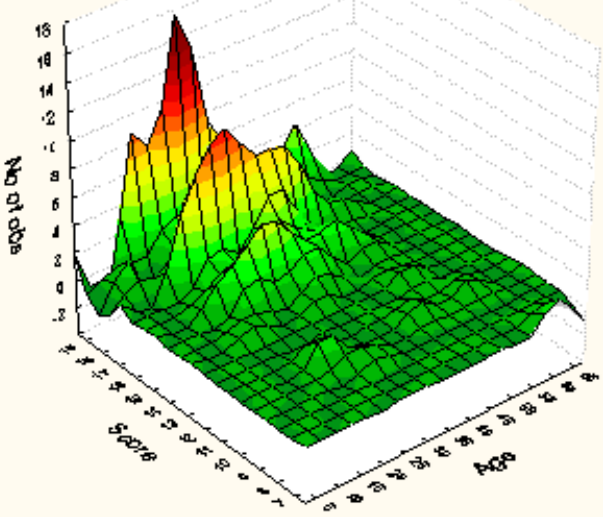

Fig. 4. Bivariate histogram for age/score correlation 
The obtained answers deal with eye contact, motoric abilities, nonverbal communication, social abilities and emotions of the child, which are core symptoms for ASD. In this context, the obtained scores are relevant for further observation and definitive diagnosis.

In the further treatment at the Hospital only 45 children of the sample were included. The main therapeutic protocol we used were Discrete Trial Training (DTT) and Joint Attention, Symbolic Play, Engagement, and Regulation (JASPER). DTT is an adult-led, highly structured, behavioural teaching approach, which is considered to have the strongest evidence as a "standard of care" for young children with autism. DTT emphasizes didactic, adult-led instruction. DTT is aimed to teach specific skills, to accelerate the overall development and to increase school readiness. In order to meet these goals, the interventionist works to create an engaging environment to support the child's ability to attend to the instruction and demonstrate the skills correctly. It comprises 2 x60 minute sessions per week in community setting.

JASPER is a developmentally based behavioural intervention that assumes that communication develops from social interactions in which specific social engagement strategies, symbolic representations, and early communication forms are modelled and naturally reinforced by the adult's responses to the child. JASPER uses the child's current play level to choose appropriate toys and materials to create a context for learning. The goal of JASPER is to increase (a) joint engagement, (b) initiations of joint attention and requesting skills, (c) diversity in social play involving objects and persons, and (d) verbal and nonverbal communication by facilitating meaningful social interactions. Additionally, most of the children obtained the treatment for sensory integration, speech and language therapy or treatments from the special educators and rehabilitators at other sites.

\section{DISCUSSION}

Having in mind the progressive incidence of this neurodevelopmental disorder, the main purpose of the researchers is to find the cause of autism, which is unfortunately still not well known. Genetics, as well as some environmental factors, are currently discussed and evaluated. However, it is very important for the later development of the child to make the diagnosis as early as possible and to include different available therapies. The prenatal diagnosis is still not possible.

In the following, we will discuss only the newest interesting information related to ASD.

In a study of Blanken et al. (2018) [18] the altered trajectories of brain growth in the prenatal period and in the first year of life are reported as very important the for postnatal autistic symptoms severity. However, no consistent association across evaluated cohorts of children between prenatal head growth have been found among the individuals with ASD and controls.

It is well documented that ASD is a disorder predominantly diagnosed in male population. However, some newest studies evaluated the gender identity in ASD patients [19].

Gender identity is a different construct from sex assigned at birth, which is typically classified as male or female primarily based on external genitalia. Some individuals are born with chromosomal, genital, or hormonal sex-characteristics which vary from the male-female binary (intersex individuals) and who may be assigned as or raised as males or females. Concerning the gender dysphoria (GD) some large studies confirmed that between $4.8 \%$ and $26 \%$ of the individuals who present at GD clinics have an autism diagnosis based on several different criteria. Gender dysphoria is the feeling of discomfort or distress that might occur in people whose gender identity differs from their sex assigned at birth or sex-related physical characteristics.

Atypical sensory sensitivity, which is one core feature of autism, was shown to be elevated in transgender and gender-diverse individuals. It is interesting to point out that many studies showed that transgender and gender-diverse individuals, compared to normal individuals, have: (1) elevated rates of autism diagnosis; (2) elevated autistic traits, systemizing traits, sensory hypersensitivity traits, and reduced empathy traits, all related to autism; and (3) elevated rates of any of six neurodevelopmental and psychiatric conditions that commonly co-occur with autism (attention-deficit/hyperactivity disorder, major depressive disorder, bipolar disorder, obsessive-compulsive disorder, learning disorder and schizophrenia. 
Concerning the gender, some new studies confirmed that autistic girls experience more overall physical health challenges compared to non-autistic girls and to autistic boys. Contrary, emerging evidence suggests increased prevalence of epilepsy in autistic girls compared to controls. The literature also suggests increased endocrine and reproductive health conditions in autistic girls/women compared to non-autistic girls/women. However, the findings regarding gastrointestinal, metabolic, nutritional, and immune-related conditions are preliminary and inconsistent [20].

There is a growing evidence that autistic girls with higher IQ use the camouflaging effects which may affect performance on gold-standard diagnostic measures [21].

Beside different well known problems, in a study of Claudia Carmassi et al. (2019) it was proven than children and adults with ASD often experience sleep disturbances and alteration of circadian sleep rhythmicity. It was supposed that low melatonin level due to abnormalities in the expression of genes regulating melatonin in autistic personalities is a cause for sleep disturbances [22].

Many studies showed that autism and depression often co-occur. In a very new study of Barbara FC van Heijst et al. (2020) evaluated that overlapping symptoms do not fully explain the co-occurrence of autism and depression and the perception of having control over your life, that is, mastery seems a relevant factor in connecting autism and depression [23].

Currently, the diagnosis of ASD must be based on criteria in DSM-5. Additionally, different checklists were structured for screening the disorder before definitive medical diagnosis.

The Autism Behaviour Checklist (ABC) is a checklist of non-adaptive behaviours; capable of providing how an individual "Looks" in comparison to others. This checklist reflects an individual's challenges to respond appropriately to daily life situation. The checklist must be completed by parents or teachers where they indicate the presence of nor presence of autism. The scale was developed in 1980 and has not undergone revision since then. The $\mathrm{ABC}$ consists of 57 item and 5 scales (1) Sensory, (2) Relating, (3) Body and Object use, (4) Language and (5) Social and Self-help [24].
The ASD checklist for parents and teachers is not a diagnostic tool. It is designed to create discussion between schools, teachers, parents, healthcare providers, and children about their educational needs. The chart was created by Hannah Grieco M.Ed. for ParentingPod.com, a resource for parents and educators on mental health and wellbeing [25].

ARI's Diagnostic Checklist, Form E-2, was developed by D-r. Bernard Rimland to diagnose children with Canner's syndrome, which is also known as 'classical autism.' Form E-2 is available on request in English. The available files contain information on over 40,000 children from more than 60 countries [26]. Baron-Cohen et all. published the first CHAT version in 1992 [27].

Concerning the early screening, the modified Checklist for autism, revised with follow-up (M-CHAT-R) is currently the best test for detection the autistic traits. This instrument is translated in several languages, as well as in the Macedonian language by Tatjana Zorcec (in 2014). The best work for early diagnosis is just to fulfil the checklist in the primary care setting. Unfortunately, our effort for delivering the list to all primary paediatrician and to obtain the answer for all children in our country was not successful.

This is the reason why we analyse in this report the utility of this instrument in children which are directed for diagnosis at the tertiary level of health service, the University Children's Hospital in Skopje.

The revised Modified Checklist for Autism in Toddlers (M-CHAT-R) is now commonly used, with recommendations to screen at 18 and 24 months of age. Some researchers from 20 clinics responded on "How good is the M-CHAT". The authors evaluated more than 36,000 toddlers, of whom $73 \%$ were screened and $1.4 \%$ subsequently diagnosed with ASD. The good news is that children who screened positive were more likely to be diagnosed with ASD and were picked up earlier $(38.5$ vs. 50.6 months $(\mathrm{p}<0.001)$ than children not screened. The bad news is that Hispanic children in this study were less likely to be screened. In addition, the authors found that the positive predictive value was not as good (18\%) when the M-CHAT was used in real-world settings and that the sensitivity of the M-CHAT was only $33 \%$, suggesting that most children who subsequently are diagnosed with autism are missed by the M-CHAT [28]. 
The Modified Checklist for Autism in Toddlers Revised-Albanian screener (M-CHAT$\mathrm{R} / \mathrm{A}$ ) was used to screen 2,594 toddlers, aged 16-30 months, at well-child visits. The finding showed that $9.75 \%$ screened were positive; follow up on failed items were conducted by phone with $50 \%$; the remainder were lost to follow-up. The $21 \%$ toddlers continued to screen positive; 19 received full evaluations, which assessed for ASD with the Autism Diagnostic Observation Schedule and developmental delays with the Parents Assessment of Developmental Status Developmental Milestones. All evaluated children had significant delays [29].

Lewis First, the Editor in Chief of Paediatrics, July 06, 2020 believe that the M-CHAT, when relied on as the sole screening tool for diagnosing a child with ASD, is not enough and other strategies and solutions need to be introduced if we are going to identify as many children as possible with ASD [30].

\section{CONCLUSIONS}

Autistic spectrum is currently the most common neurodevelopmental disorder in children.

The cause is related to genetics as well as to environmental trigger factors.

Early childhood screening for autism is essential for all children and early intervention can have a tremendous impact on prognosis.

For screening we propose the use of M-CHAT-R/F which is currently the most exact test which allows the early suspicion, but also a possible follow up the symptoms of this disorder.

The early diagnosis and treatment are essential because only in that way a possible maximal success in skills is guaranteed.

\section{REFERENCES}

1. American Psychiatric Association. Diagnostic and Statistical Manual of Mental Disorders, 5th - Text revision ed. Washington, DC: American Psychiatric Association; 2000.

2. Centres for Disease Control and Prevention (CDC). Data \& Statistics on Autism Spectrum Disorder: U.S. Department of Health \& Human
Services; 2020 [cited 2020 May 6th]. Available from: https://www.cdc.gov/ncbddd/autism/data. html.

3. Maenner MJ. Prevalence of Autism Spectrum Disorder Among Children Aged 8 Years-Autism and Developmental Disabilities Monitoring Network, 11 Sites, United States, 2016. MMWR Surveillance Summaries. 2020; 69(4): 1-12.

4. Fernandes R. Child Behaviour Checklist (CBCL) - Assessing Emotional \& Behavioural Problems in Children. June 9, 2020.

5. Chlebowski C, Robins D, Barton M, Fein D. Large-scale use of the modified checklist for autism in low-risk toddlers. Pediatrics. 2013 Apr; 131(4): e1121-7.

6. Baron-Cohen, S., Wheelwright, S., Cox, A., Baird, G., Charman, T., Swettenham, J., Drew, A., \& Doehring, P. (2000). Early identification of autism by the CHecklist for Autism in Toddlers. Journal of the Royal Society of Medicine, 93, 521-525.

7. Robins D, Casagrande K, Barton M Chen Ch., Dumont-Mathieu T, Fein D. Validation of the modified checklist for Autism in toddlers, revised with follow-up (M-CHAT-R/F). Pediatrics, 2014 Jan; 133(1): 37-45.

8. Zwaigenbaum L. et al., Autism Screening: Where Do We Go From Here?, Pediatrics, October 2019, 144 (4) e20190925; DOI: https://doi. org/10.1542/peds.2019-0925.

9. Wong V, Hui L, Lee W, Leung L, Ho P, Lau W, Fung C, Chung B. A modified screening tool for autism (Checklist for Autism in Toddlers [CHAT23]) for Chinese children. Pediatrics, 2004 Aug; 114(2): e166-76.

10. 10. Robins, D. L., Fein, D., \& Barton, M. (1999). Modified Checklist for Autism in Toddlers (M-CHAT). Self-published. See www. mchatscreen.com.

11. 11. Robins, D. L., Fein, D., Barton, M. L., \& Green, J. A. The Modified Checklist for Autism in Toddlers: An initial study investigating the early detection of autism and pervasive developmental disorders. Journal of Autism and Developmental Disorders, 2001; 31(2), 131-144.

12. Robins D-I: a tool for assessing risk of bias in non-randomised studies of interventions, $B M J$ 2016; 355: 14919.

13. Robins, D.L. \& Dumont-Mathieu, T. The Modified Checklist for Autism in Toddlers (M-CHAT): A review of current findings and future directions. Journal of Developmental and Behavioral Pediatrics, 2006; 27(Supplement 2), S111-S119. PMID: 16685177.

14. Robins, D. L. Screening for autism spectrum disorders in primary care settings. Autism: The International Journal of Science and Practice, 2008; 12 (5), 537-556. 
15. Robins, D. L., Fein, D., \& Barton, M. (2009). Modified Checklist for Autism in Toddlers, revised, with follow-up (M-CHAT-R/F). Self-published. See www.mchatscreen.com.

16. 16. Robins, D. L., Casagrande, K., Barton, M., Chen, C. M. A., Dumont-Mathieu, T., \& Fein, D. Validation of the modified checklist for autism in toddlers, revised with follow-up (M-CHATR/F). Pediatrics, 2014; 133(1), 37-45.

17. Khowaja M., Robins D.L. Checklist for Autism in Toddlers (CHAT). In: Volkmar F. (eds) Encyclopedia of Autism Spectrum Disorders. 2018, Springer, New York, NY. https://doi. org/10.1007/978-1-4614-6435-8 263-3.

18. Blanken L, Dass A, Alvares G, van der Ende J, Schoemaker N, Marroun H, Hickey M, et al. A prospective study of foetal head growth, autistic traits and autism spectrum disorder. Autism Res. 2018 Apr; 11(4): 602-612.

19. Warrier V, Greenberg D, Weir E, Buckingham C, Smith P, Lai MC, Allison C, Baron-Cohen S. Elevated rates of autism, other neurodevelopmental and psychiatric diagnoses, and autistic traits in transgender and gender-diverse individuals. Nat Commun. 2020; 11: 3959.

20. Kassee C, Babinski S, Tint A, Lunsky Y, Brown $\mathrm{H}$, Ameis S, Szatmari P, Lai MC, Einstein G. Physical health of autistic girls and women: a scoping review. Mol Autism. 2020; 11: 84. Published online 2020 Oct 27. doi: 10.1186/s13229020-00380-z.

21. Ratto A, Kenworthy L, Yerys B, Bascom J, Trubanova Wieckowski A, White S, Wallace G, Pugliese C, Schultz R, Ollendick T, Scarpa A, Seese S, Register-Brown K, Martin A, Gutermuth L. What About the Girls? Sex-Based Differences in Autistic Traits and Adaptive Skills. J Autism Dev Disord. 2018 May; 48(5): 1698-1711.

22. Carmassi C, Palagini L, Caruso D, Masci I, Nobili L, Vita A, and Dell'Osso L. Systematic Review of Sleep Disturbances and Circadian Sleep Desynchronization in Autism Spectrum Disorder: Toward an Integrative Model of a Self-Reinforcing Loop. Front Psychiatry. 2019; 10: 366.

23. Van Heijst B, Deserno M, Rhebergen D,... Autism and depression are connected: A report of two complimentary network studies. Autism, 2020, Vol. 24(3) 680-692.

24. Davenport T.L. (2011) Autism Behavior Checklist. In: Goldstein S., Naglieri J.A. (eds) Encyclopedia of Child Behavior and Development. Springer, Boston, MA.

25. Hannah Grieco M. Parent Checklist for Autism Spectrum Disorder Ed. for ParentingPod.com.

26. Rimland B. Diagnostic Checklist Form E-2 and Research Questionnaire Form E-3 | Autism Research Institute, December 21, 2012.

27. Khowaja M., Robins D.L. (2018) Checklist for Autism in Toddlers (CHAT). In: Volkmar F. (eds) Encyclopedia of Autism Spectrum Disorders. Springer, New York, NY. https://doi. org/10.1007/978-1-4614-6435-8 263-3.

28. Johnson CP, Myers S, Lipkin P, Cartwright D, Desch L, Duby J, et al. Identification and evaluation of children with autism spectrum disorders. Pediatrics, 2007; 120 (5): 1183-1215.

29. Brennan L, Fein D, Como A, Carcani Rathwell I, Chen C, Use of the Modified Checklist for Autism, Revised with Follow up-Albanian to Screen for ASD in Albania. J Autism Dev Disord. 2016 Nov; 46(11): 3392-3407.

30. First L., Finding Opportunities to Improve Screening for Autism, AAP News, 2020. 


\title{
Резиме
}

\section{ДАЛИ М-СНАТ-R ДАВА ВАЖНИ ИНФОРМАЦИИ ЗА ДИЈАГНИОЗА НА АУТИЗМОТ?}

\author{
Нада Поп-Јорданова ${ }^{1}$, Татјана Зорчец ${ }^{2}$ \\ ${ }^{1}$ Македонска академија на науките и уметностите, Скопје, РС Македонија \\ ${ }^{2}$ Универзитетска клиника за детски болест, Скопје, РС Македонија
}

Имајќи ги предвид растечките бројки на инциденција за аутизмот низ целиот свет, раната дијагноза на ова невроразвојно растројство има висок приоритет. За таа цел се конструирани и употребувани неколку прашалници. Сепак, не постојат единствени и универзални критериуми за процена и дијагноза на аутизмот, а дури и да постојат, не секоја земја има доволно ресурси за да менаџира ваква процена. особености.

Од неодамна ревидираната валидизирана верзија на М-СНАТ покажа строги психометриски

Целта на оваа статија е дискусија за нашите резултати добиени со примена на M-CHAT-R на примерок од 131 дете, со средна возраст 31,9 9 9,4 месеци, пратени за дијагноза и третман на Универзитетската клиника за детски болести во Скопје.

Нашите резултати потврдуваат дека скринингот со M-CHAT-R/F моментално е многу точен тест, кој овозможува рано сомневање, но и следење на симптомите на ова растројство. Дополнително, со истражувањето покажавме дека постои статистички значајна негативна корелација меѓу возраста и добиените резултати на тестот.

Клучни зборови: аутизам, чек-листа, скрининг, невроразвојно растројство 